\title{
MEMPERTAHANKAN DAN MENGEMBANGKAN BISNIS DITENGAH MARAKNYA PANDEMI COVID-19
}

Khotiza Anisa, Zuhrinal M. Nawawi

Universitas Islam Negeri (UIN) Sumatera Utara, Medan, Indonesia.

Email: khotizaanisa1502@gmail.com,zuhrinal.nawawi@uinsu.ac.id

\begin{tabular}{ll}
\hline INFO ARTIKEL & ABSTRAK \\
\hline Diterima & Meningkatnya masalah yang ditimbulkan sang covid-19 ini sangat \\
15 Desember 2021 & merugikan bagi seluruh pihak. Pada masa pandemi covid-19 yang sedang \\
Direvisi & dialami bangsa Indonesia ketika ini, diharapkan taktik \& upaya lebih \\
21 Desember 2021 & keras lagi bagi para pelaku bisnis khususnya UMKM buat bisa \\
Disetujui & mempertahankan usahanya. Oleh karenanya supaya keberlangsungan \\
2 Januari 2022 & bisnis permanen berjalan, diharapkan pemberdayaan ekonomi warga \& \\
\hline Kata Kunci: & pendampingan yang menstimulus pengusaha mini buat bisa menyebarkan \\
Strategi, covid19, & usahanya secara berkelanjutan. Hasil penelitian ini merekomendasi taktik \\
pengembangan & bertahan buat UMKM berupa melakukan perdagangan secara E- \\
usaha pada tengah & Commerce, melakukan pemasaran secara digital, melakukan pemugaran \\
pandemic & $\begin{array}{l}\text { kualitas produk \& penambahan layanan dan menjalin \& mengoptimalkan } \\
\text { interaksi pemasaran pelanggan. Hasil penelitian ini krusial buat dipahami }\end{array}$ \\
& sang pelaku usaha \& dibutuhkan pelaku usaha selalu responsif \& \\
& mengikuti keadaan terhadap perubahan lingkungan supaya sanggup terus \\
& bertahan.
\end{tabular}

\section{ABSTRACT}

The increasing problem caused by the covid-19 is very detrimental to the all sides. At the time of the covid-19 pandemic that is being experienced by the Indonesian nation today, it is expected that tactics and efforts are even harder for business people, especially MSMEs to be able to maintain their business. Therefore, so that the sustainability of permanent business runs, it is expected that the economic empowerment of citizens and assistance that stimulates mini entrepreneurs to be able to spread their business sustainably. The results of this study recommend defensive tactics for MSMEs in the form of trading E-Commerce, doing

Keywords:

Stategi, covid19, business marketing digitally, performing product quality restoration \& service development in the midst of pandemic addition and establishing \& optimizing customer marketing interactions. The results of this study are crucial to understand the business actors \& needed business actors are always responsive \& following the situation to environmental changes in order to continue to survive.

\section{Pendahuluan}

Dunia ketika ini masuk ke pada status waspada lantaran penyebaran virus baru yang penyebarannya semakin hari semakin masif. Virus ini pertama kali timbul \& ditemukan pada Wuhan, Cina, tahun 2019. Pada awal maret 2020 World Health Organitazion sudah memutuskan Virus Corona menjadi pandemi dunia (Gunawan \& Yulita, 2020). Status pandemi atau epidemi dunia ini mengindikasikan bahwa penyebaran COVID19 ini bergerak maju \& menyebar sampai hampir ke semua global. Pandemi virus COVID-19 nir hanya mengancam sektor

$\begin{array}{ll}\text { How to cite: } & \text { Anisa, Khotiza Zuhrinal M. Nawawi (2022). Mempertahankan Dan Mengembangkan Bisnis Ditengah } \\ & \text { Maraknya Pandemi Covid-19, Action Research Literate, 6(1). } \\ \text { E-ISSN: } & 2721-2769 \\ \text { Published by: } & \text { Ridwan Institute }\end{array}$


kesehatan, tetapi pula mengancam krisis ekonomi dunia. Berdasarkan data berdasarkan World Economic Outlook April 2020, IMF memprediksikan perekonomian global akan merosot sampai ke minus 3\% hingga menggunakan tahun ini. Persaingan bisnis yang semakin ketat pada era globalisasi wajib disikapi sang para pelaku usaha/bisnis menggunakan menerapkan langkah-langkah strategis bagi kelangsungan usahanya. Munculnya pandemi covid-19 yang melanda hampir pada semua global menyebabkan sendi-sendi kehidupan misalnya pendidikan \& perekonomian mengalami kelumpuhan yang menjadikan sekolah-sekolah ditutup dan perusahaan-perusahaan poly yang mengurangi kegiatan produksi \& bahkan nir sedikit yang melakukan pemutusan interaksi kerja (PHK) (Nalini, 2021).

Hal ini pula berdampak terhadap terbatasnya operasional UMKM \& berkurangnya konsumen yang berbelanja secara eksklusif dibandingkan hari biasa. Dengan ini, Pelaku Usaha bisa mengikuti keadaan menggunakan membuka toko online atau berjualan melalui E-Commerce. ECommerce mempunyai dampak positif \& signifikan terhadap peningkatan kinerja pemasaran \& pendapatan UMKM (Thaha, 2020).

Selain melakukan perdagangan ECommerce, Pelaku UMKM pula dituntut buat bisa mengkomunikasikan produk secara intensif menggunakan melakukan pemasaran produk memakai digital marketing \& memanfaatkan media umum buat bisa menjangkau konsumennya secara eksklusif \& bisa menekan porto kenaikan pangkat (Febriantoro, 2018). Efek pertama berdasarkan pandemi ini merupakan beralihnya sistem finansial perusahaan ke zero-based budgeting. Kedua merupakan adanya Pemutusan Hubungan Karyawan (PHK) akbar -besaran pada banyak sekali perusahaan. Efek ketiga merupakan kekacauan produksi yang dialami banyak sekali perusahaan. Efek keempat merupakan penurunan produktivitas perusahaan. Dampak terakhir merupakan runtuhnya perusahaan dampak kebangkrutan yang ditimbulkan ketidakmampuan perusahaan buat bertahan pada tengah pandemic (Frida, 2020).

Secara keseluruhan, pandemi ini membawa pengaruh yang sangat akbar terutama pada sektor usaha. Dampak akbar tadi tentunya bersifat negatif. Banyak perusahaan mengalami kerugian akbar. Penelitian ini bertujuan buat menggambarkan \& menjabarkan apa saja taktik bertahan yang wajib dilakukan sang pelaku UMKM sebagai akibatnya mereka bisa terus bertahan \& sebagai lebih responsif terhadap perubahan iklim usaha terutama ketika terjadi covid-19. Pemerintah Indonesia berupaya buat mengatasi pertarungan tadi menggunakan mengeluarkan beberapa kebijakan khususnya pada bidang perekonomian supaya pertarungan pandemi covid-19 ini nir menyebabkan resesi ekonomi yang berkepanjangan (Jati \& Putra, 2020). Perusahaan akbar, menengah, \& mini yang masih bisa bertahan melakukan beberapa langkah konkrit supaya output produksinya permanen bisa dipasarkan. Pemasaran secara online melalui media adalah langkah sempurna yang wajib dilakukan sang para pelaku bisnis (Suswanto \& Setiawati, 2020) Oleh karenanya taktik yang diterapkan sang para pelaku bisnis ini wajib dilakukan secara optimal supaya produk yang didapatkan bisa diterima sang warga menggunakan menaruh informasi yang kentara \& bonafide konsumen.

\section{Metode Penelitian}

Metode kualitatif merupakan jenis metode yang dipakai pada penelitian ini (Nugrahani \& Hum, 2014). Metode Penelitian Kualitatif merupakan metode yang lebih menekankan dalam aspek pemahaman secara mendalam terhadap suatu perkara daripada 
melihat pertarungan buat penelitian generalisasi. Metode penelitian ini lebih senang memakai Teknik analisis mendalam (in-depth analysis) (Rukin, 2019), yaitu mempelajari perkara secara masalah perkasus lantaran metodologi kualitatif konfiden bahwa sifat suatu perkara satu akan tidak sinkron menggunakan sifat berdasarkan perkara lainnya.

\section{Hasil dan Pembahasan}

Data yang dirilis sang website corona. https://www.worldometers.info/coronavirus/ per tiga April 2020, memperlihatkan bahwa Indonesia berada dalam urutan pertama diantara negara-negara ASEAN. Kebijakan \& upaya pencegahan skala sebaran COVID-19 yang pertama kali diumumkan sang Presiden Joko Widodo, dua Maret 2020, sudah berimbas dalam perubahan cara \& ritme majemuk kegiatan, baik sosial kemasyarakatan, pelayanan public juga aktivitas usaha.

Pengaruh Corona ini sangat berdampak bagi kehidupan warga, dimana peraturan atau kebijakan yang sudah ditetapkan sang pemerintah tadi tentu sangat berpengaruh terhadap segala sisi kehidupan. Hal ini sangat berdampak terhadap perekonomian, global bisnis \& Pendidikan (Saniya, 2021). Diantaranya mengakibatkan beberapa hal, yakni perekonomian warga menurun, Perekonomian Negara menurun drastis, COVID-19 pula mensugesti industry \& sektor bisnis. Menteri Koordinator Bidang Perekonomian, Airlangga Hartarto menyampaikan, tidak hanya industri yang terganggu, pandemi COVID-19 pula akan menambah pengangguran. Berdasarkan output observasi, homogen-homogen UMKM mencicipi penurunan omzet selama adanya COVID-19. Hal ini terjadi lantaran mulai berkurangnya kegiatan yang dilakukan diluar rumah, kesulitan pada memperoleh bahan standar lantaran terjadi hambatan transportasi, dan mulai turunnya agama warga terhadap produk yang terdapat pada luar terutama bidang kuliner. UMKM yang adalah galat satu penopang perekonomian lantaran pula poly menyediakan lapangan pekerjaan, menggunakan adanya COVID-19 ini, pula mulai terdapat yang melakukan PHK atau merumahkan karyawan ada interim lantaran perusahaan/bisnis mereka wajib tutup ad interim ketika.

Setiap pebisnis tentu menginginkan usahanya sukses \& permanen survive pada tengah pandemi corona ini. Ada kiat-kiat eksklusif supaya usaha permanen survive walau pada landa badai (Wijayanti et al., 2021). Berikut taktik mempertahankan usaha pada tengah pandemi:

1. Memiliki agama diri \& kemandirian yang tinggi Setiap pebisnis wajib mempunyai rasa percaya diri yang tinggi, Setiap usaha apapun yang dilakukan tentu mempunyai faktor risiko. Tanpa agama yang tinggi usaha nir bisa berjalan lantaran nir berani buat menanggung segala risikonya.

2. Berbisnis yang halal, mulai berdasarkan modal, proses, sampai penjualan Modal bisnis sangat krusial, meski demikian wajib dihasilkan menggunakan cara yang baik, nir curang. Proses pada berbisnis pun pula dijalankan menggunakan caracara yang baik pula, jujur, nir melakukan monopoli, \& kecurangan.

3. Melakukan ekspor \& impor barang Pebisnis wajib mempunyai pangsa pasar yang luas. Dengan melakukan aktivitas ekspor \& impor barang berarti sudah memperluas pangsa pasar. Semakin luas pangsa pasar yang diciptakan, maka semakin akbar sasaran penjualan \& laba yang dihasilkan. Seorang pebisnis wajib kreatif mencari \& membangun peluang pasar, menaikkan produktivitas, \& efisien.

4. Menjaga agama rekanan usaha Hal ini sangat krusial bagi maju mundurnya bisnis yang dilakukan. Menjaga agama 
rekanan usaha menggunakan cara menjaga kualitas barang \& pula menepati pembayaran sinkron menggunakan ketika yang telah ditentukan.

5. Melakukan kenaikan pangkat barang yang diperdagangkan yaitu menggunakan menciptakan iklan baik pada media elektronika juga media cetak. Pada era kini kenaikan pangkat bisa dilakukan menggunakan mudah, yaitu melalui social media yang mempunyai follower sangat poly \& luas, bisa menjangkau banyak sekali belahan global.

6. Berbisnis barang kebutuhan dasar Bisnis yang sangat menjanjikan merupakan usaha barang kebutuhan dasar. Hal ini dikarenakan barang kebutuhan dasar mempunyai 2 sifat, yaitu long lasting \& fast moving. Dalam global usaha long lasting diartikan bisa bertahan pada ketika yang using buat dikelola menjadi sebuah bisnis, lantaran bisnis yang peluangnya nir menentu, kemungkinan mini sanggup membuat laba yang signifikan. Barang kebutuhan dasar akan selalu dicari \& diharapkan sang semua lapisan warga buat memenuhi kebutuhan mereka, lantaran kebutuhan ini sifatnya primer.

\section{Kesimpulan}

Dari output penelitian yang dilakukan, maka bisa disimpulkan bahwa Pandemi covid-19 yang terjadi pada Indonesia berdampak dalam ketidak stabilan pada perekonomian terutama dalam UMKM. Pelaku UMKM ini mencicipi pengaruh eksklusif berupa menurunnya nomor penjualan dikarenakan adanya himbauan pemerintah \& penerapan PSBB yang menghimbau warga buat permanen dirumah sebagai akibatnya relatif poly UMKM yang wajib berhenti beroperasi buat ad interim ketika. Untuk itu pelaku UMKM wajib mempunyai taktik buat bisa bertahan pada tengah pandemik ini \& dituntut buat bisa mengikuti keadaan terhadap syarat yang terjadi. Untuk mempertahankan kelangsungan bisnis mini (UMKM) pemanfaatan internet \& media umum adalah taktik yang sangat sempurna pada tengah pandemi covid-19 ini. Tetapi demikian penggunaan teknologi pula membutuhkan porto yang nir sedikit dan asal daya insan yang mempunyai kemampuan pada bidang teknologi kabar.

\section{BIBLIOGRAFI}

Febriantoro, W. (2018). Kajian dan strategi pendukung perkembangan e-commerce bagi UMKM Di Indonesia. Manajerial: Jurnal Manajemen Dan Sistem Informasi, 17(2), 184-207.Google Scholar

Frida, N. (2020). Analisis Strategi Mempertahankan dan Mengembangkan Bisnis di Tengah Pandemi COVID-19 Serta Mengetahui Dampak Perkembangan dan Pertumbuhan COVID-19 di Indonesia. Jurnal Aktiva: Riset Akuntansi Dan Keuangan, 2(3), 26-36. Google Scholar

Gunawan, C. I., \& Yulita, S. E. (2020). Anomali Covid-19: Dampak Positif Virus Corona Untuk Dunia. IRDH Book Publisher. Google Scholar

Jati, B. J. B., \& Putra, G. R. A. (2020). Optimalisasi upaya pemerintah dalam mengatasi pandemi covid 19 sebagai Bentuk pemenuhan hak warga negara. SALAM: Jurnal Sosial Dan Budaya Syar-I, 7(5), 473-484. Google Scholar

Nalini, S. N. L. (2021). Dampak Dampak covid-19 terhadap Usaha MIkro, Kecil dan Menengah. Jesya (Jurnal Ekonomi Dan Ekonomi Syariah), 4(1), 662-669. Google Scholar

Nugrahani, F., \& Hum, M. (2014). Metode penelitian kualitatif. Solo: Cakra Books. Google Scholar 
Rukin, S. P. (2019). Metodologi Penelitian Kualitatif. Yayasan Ahmar Cendekia Indonesia. Google Scholar

Saniya, C. A. (2021). Dampak Covid-19 terhadap Aktivitas Pariwisata Kota Lama Semarang dalam Aspek Sosial Ekonomi Masyarakat. Google Scholar

Suswanto, P., \& Setiawati, S. D. (2020). Strategi Komunikasi Pemasaran Shopee Dalam Membangun Positioning Di Tengah Pandemi Covid-19 Di Indonesia. LINIMASA: Jurnal Ilmu Komunikasi, 3(2), 16-29. Google
Scholar

Thaha, A. F. (2020). Dampak covid-19 terhadap UMKM di Indonesia. BRAND Jurnal Ilmiah Manajemen Pemasaran, 2(1), 147-153. Google Scholar

Wijayanti, R., Suratman, S., \& Sugiyanto, E. K. (2021). Strategi Adaptasi Di Era Pandemi Covid 19 Bagi Umkm Kalicari Pedurungan Semarang. InEJ: Indonesian Engagement Journal, 2(1). Google Scholar

\section{Copyright holder :}

Khotiza Anisa, Zuhrinal M. Nawawi (2022).

First publication right :

Action Research Literate

This article is licensed under: 